Pacific Journal of Mathematics

REARRANGEMENT INEQUALITIES INVOLVING CONVEX 


\section{REARRANGEMENT INEQUALITIES INVOLVING CONVEX FUNCTIONS}

\section{DAVID LONDON}

Let $a=\left(a_{1}, \cdots, a_{n}\right)$ and $b=\left(b_{1}, \cdots, b_{n}\right)$ be $n$-tuples of nonnegative numbers. Then

$$
\prod_{i=1}^{n}\left(a_{i}^{\prime}+b_{i}^{\prime}\right) \leqq \prod_{i=1}^{n}\left(a_{i}+b_{i}^{\prime}\right) \leqq \prod_{i=1}^{n}\left(a_{i}^{*}+b_{i}^{\prime}\right)
$$

and

$$
\sum_{i=1}^{n} a_{i}^{*} b_{i}^{\prime} \leqq \sum_{i=1}^{n} a_{\imath} b_{i}^{\prime} \leqq \sum_{i=1}^{n} a_{i}^{\prime} b_{i}^{\prime} .
$$

$a^{\prime}=\left(a_{i}^{\prime}, \cdots, a_{n}^{\prime}\right)$ and $a^{*}=\left(a_{1}^{*}, \cdots, a_{n}^{*}\right)$ are respectively the rearrangement of $a$ in a nondecreasing or nonincreasing order. (1) was recently found by Minc and (2) is well known. In this note we show that these inequalities are special cases of rearrangement inequalities valid for functions having some convex properties.

Let $x=\left(x_{1}, \cdots, x_{n}\right)$ be an $n$-tuple of real numbers. We denote by $x^{*}=\left(x_{1}^{*}, \cdots, x_{n}^{*}\right)$ the $n$-tuple $x$ rearranged in a nonincreasing order $x_{1}^{*} \geqq x_{2}^{*} \geqq \cdots \geqq x_{n}^{*}$, and we denote by $x^{\prime}=\left(x_{1}^{\prime}, \cdots, x_{n}^{\prime}\right)$ the same $n$-tuple rearranged in a nondecreasing order $x_{1}^{\prime} \leqq x_{2}^{\prime} \leqq \cdots \leqq x_{n}^{\prime}$.

Recently Minc [2] proved that if $a=\left(a_{1}, \cdots, a_{n}\right)$ and $b=\left(b_{1}, \cdots, b_{n}\right)$ are real $n$-tuples such that $a_{i}, b_{i} \geqq 0, i=1, \cdots, n$, then

$$
\prod_{i=1}^{n}\left(a_{i}^{\prime}+b_{i}^{\prime}\right) \leqq \prod_{i=1}^{n}\left(a_{i}+b_{i}^{\prime}\right) \leqq \prod_{i=1}^{n}\left(a_{i}^{*}+b_{i}^{\prime}\right) .
$$

If $a_{i}>0$ and $b_{i} \geqq 0, i=1, \cdots, n$, then (1) is equivalent to

$$
\sum_{i=1}^{n} \log \left(1+\frac{b_{i}^{\prime}}{a_{i}^{\prime}}\right) \leqq \sum_{i=1}^{n} \log \left(1+\frac{b_{i}^{\prime}}{a_{i}}\right) \leqq \sum_{i=1}^{n} \log \left(1+\frac{b_{i}^{\prime}}{a_{i}^{*}}\right) \cdot
$$

(see also [4, Theorem 2] and [5]).

It is well known [1, Th. 368] that if $a=\left(a_{1}, \cdots, a_{n}\right)$ and $b=\left(b_{1}, \cdots, b_{n}\right)$ are real $n$-tuples, then

$$
\sum_{i=1}^{n} a_{i}^{*} b_{i}^{\prime} \leqq \sum_{i=1}^{n} a_{i} b_{i}^{\prime} \leqq \sum_{i=1}^{n} a_{\imath}^{\prime} b_{i}^{\prime} .
$$

If $a_{\imath}>0$ and $b_{i} \geqq 0, i=1, \cdots, n$, then (2) is obviously equivalent to

$$
\sum_{i=1}^{n}\left(\frac{b_{i}^{\prime}}{a_{i}^{\prime}}\right) \leqq \sum_{i=1}^{n}\left(\frac{b_{i}^{\prime}}{a_{i}}\right) \leqq \sum_{i=1}^{n}\left(\frac{b_{i}^{\prime}}{a_{i}^{*}}\right) .
$$

In the present note we generalize $(1)^{\prime}$ and $(2)^{\prime}$ for more general 
functions. An inequality analogue to (1)' is proved for functions $f(x)$ such that $f\left(e^{x}\right)$ is convex (Theorem 1), and an inequality analogue to (2)' is proved for convex functions $f(x)$ (Theorem 2).

In our proof we use the following theorem of Mirsky [3]: Given two $n$-tuples $x=\left(x_{1}, \cdots, x_{n}\right)$ and $y=\left(y_{1}, \cdots, y_{n}\right)$ such that $x_{i} \geqq 0$ and $y_{i} \geqq 0, i=1, \cdots, n$. If

$$
\sum_{i=1}^{k} y_{i}^{*} \leqq \sum_{i=1}^{k} x_{i}^{*}, \quad k=1, \cdots, n,
$$

then $y$ lies in the convex hull of the set of vectors $\left(\delta_{1} x_{\tau(1)}, \cdots, \delta_{n} x_{\tau(n)}\right)$, where each $\delta_{i}$ takes the values 0 or 1 and $\tau$ ranges over all permutations of $(1, \cdots, n)$.

\section{Two rearrangement inequalities.}

THEOREM 1. Let $a=\left(a_{1}, \cdots, a_{n}\right)$ and $b=\left(b_{1}, \cdots, b_{n}\right)$ be n-tuples satisfying $a_{i}>0$ and $b_{i} \geqq 0, i=1, \cdots, n$. Let $f(x)$ be a real valued function defined for $x \geqq 1$ such that $F(x)=f\left(e^{x}\right)$ is convex for $x \geqq 0$ and $f(1) \leqq f(x)$ for $x \geqq 1$. Then

$$
\sum_{i=1}^{n} f\left(1+\frac{b_{i}^{\prime}}{a_{i}^{\prime}}\right) \leqq \sum_{i=1}^{n} f\left(1+\frac{b_{i}^{\prime}}{a_{i}}\right) \leqq \sum_{i=1}^{n} f\left(1+\frac{b_{i}^{\prime}}{a_{i}^{*}}\right) .
$$

If $F(x)$ is strictly convex, then equality in the right inequality of (3) holds if and only if $b^{\prime} / a^{*}=\left(b_{1}^{\prime} / a_{1}^{*}, \cdots, b_{n}^{\prime} / a_{n}^{*}\right)$ is a rearrangement of $b^{\prime} / a=\left(b_{1}^{\prime} / a_{1}, \cdots, b_{n}^{\prime} / b_{n}\right)$, and equality in the left inequality of (3) holds if and only if $b^{\prime} / a^{\prime}=\left(b_{1}^{\prime} / a_{1}^{\prime}, \cdots, b_{n}^{\prime} / a_{n}^{\prime}\right)$ is a rearrangement of $b^{\prime} / a$.

Proof. We first prove the theorem for $n=2$. In this case the theorem becomes: Let $0<a_{1} \leqq a_{2}$ and $0 \leqq b_{1} \leqq b_{2}$. Then

$$
f\left(1+\frac{b_{1}}{a_{1}}\right)+f\left(1+\frac{b_{2}}{a_{2}}\right) \leqq f\left(1+\frac{b_{1}}{a_{2}}\right)+f\left(1+\frac{b_{2}}{a_{1}}\right) .
$$

If $F(x)$ is strictly convex, then equality in (4) holds if and only if $a_{1}=a_{2}$ or $b_{1}=b_{2}$.

Denote

$$
1+\frac{b_{1}}{a_{1}}=u_{1}, \quad 1+\frac{b_{2}}{a_{2}}=u_{2}, 1+\frac{b_{2}}{a_{1}}=v_{1}, 1+\frac{b_{1}}{a_{2}}=v_{2} .
$$

We have,

$$
1 \leqq u_{1} \leqq v_{1}, \quad 1 \leqq u_{2} \leqq v_{1}
$$

By (1) for $n=2$, or directly, we obtain 


$$
\begin{aligned}
u_{1} u_{2} & =\left(1+\frac{b_{1}}{a_{1}}\right)\left(1+\frac{b_{2}}{a_{2}}\right)=\frac{\left(a_{1}+b_{1}\right)\left(a_{2}+b_{2}\right)}{a_{1} a_{2}} \\
& \leqq \frac{\left(a_{1}+b_{2}\right)\left(a_{2}+b_{1}\right)}{a_{1} a_{2}}=\left(1+\frac{b_{2}}{a_{1}}\right)\left(1+\frac{b_{1}}{a_{2}}\right)=v_{1} v_{2} .
\end{aligned}
$$

Denote

$$
\log u_{i}=\tilde{u}_{i}, \log v_{i}=\widetilde{v}_{i},
$$$$
i=1,2 \text {. }
$$

From (5), (6) and (7) it follows that

$$
\left\{\begin{array}{l}
\tilde{u}_{1} \leqq \widetilde{v}_{1}, \widetilde{u}_{2} \leqq \widetilde{v}_{1} \\
\widetilde{u}_{1}+\widetilde{u}_{2} \leqq \widetilde{v}_{1}+\widetilde{v}_{2}
\end{array}\right.
$$

By the theorem of Mirsky stated above, it follows from (8) that $\tilde{u}=\left(\tilde{u}_{1}, \tilde{u}_{2}\right)$ lies in the convex hull of the set of vectors $\left(\delta_{1} \widetilde{v}_{\tau(1)}, \delta_{2} \widetilde{v}_{\tau(2)}\right)$, where $\delta_{1}$ and $\delta_{2}$ take the values 0 or 1 and $\tau$ is a permutation of $(1,2)$. As $F(x)=f\left(e^{x}\right)$ is convex for $x \geqq 0, F\left(x_{1}\right)+F\left(x_{2}\right)$ is convex in the quadrant $x_{1} \geqq 0, x_{2} \geqq 0$ and thus obtains its maximum in the above convex hull on one of its vertices. Hence,

$$
\begin{aligned}
& f\left(1+\frac{b_{1}}{a_{1}}\right)+f\left(1+\frac{b_{2}}{a_{2}}\right)=f\left(u_{1}\right)+f\left(u_{2}\right)=F\left(\widetilde{u}_{1}\right)+F\left(\widetilde{u}_{2}\right) \\
\leqq & \max \left\{F\left(\delta_{1} \widetilde{v}_{\tau(1)}\right)+F\left(\delta_{2} \widetilde{v}_{\tau(2)}\right)\right\} \leqq F\left(\widetilde{v}_{1}\right)+F\left(\widetilde{v}_{2}\right) \\
= & f\left(v_{1}\right)+f\left(v_{2}\right)=f\left(1+\frac{b_{1}}{a_{2}}\right)+f\left(1+\frac{b_{2}}{a_{1}}\right) .
\end{aligned}
$$

Here we used the fact that $F(0) \leqq F(x)$ for $x \geqq 0$. (4) is thus proved.

It is obvious that if $a_{1}=a_{2}$ or $b_{1}=b_{2}$ then equality holds in (4). We have to show that if $F(x)$ is strictly convex and if

$$
0<a_{1}<a_{2} \text { and } 0 \leqq b_{1}<b_{2}
$$

then the inequality in (4) is strict. As $F(x)$ is strictly convex, it is enough to show that if (9) holds then $\widetilde{u}$ does not coincide with one of the vertices $\left(\delta_{1} \widetilde{v}_{\tau(1)}, \delta_{2} \widetilde{v}_{\tau(2)}\right)$. From (9) follows $\widetilde{u}_{1}<\widetilde{v}_{1}$ and $\widetilde{u}_{2}<\widetilde{v}_{1}$. Therefore if $\tilde{u}=\left(\widetilde{u}_{1}, \widetilde{u}_{2}\right)$ is a vertex, then $\widetilde{u}_{1}=0$ or $\widetilde{u}_{2}=0$. But $b_{2}>0$. Hence, $\widetilde{u}_{1}=0$ and $\left(\widetilde{u}_{1}, \widetilde{u}_{2}\right)$ coincides with the vertex $\left(0, \widetilde{v}_{2}\right)$. But from $\widetilde{u}_{2}=\widetilde{v}_{2}$ it follows that $b_{1}=b_{2}$, which contradicts (9).

The theorem for $n \geqq 3$ follows now by induction on $n$ as in [2].

We prove the right inequality of (3) together with its equality statement.

If $a_{1}=a_{1}^{*}$ then the result, including the equality statement, follows by the induction.

Assume now that $a_{1}=a_{k}^{*}$ and $a_{l}=a_{1}^{*}$, where $k, l \neq 1$. Using the proved result for $n=2$ and the induction hypothesis for $n-1$, we obtain 


$$
\begin{aligned}
\sum_{i=1}^{n} f\left(1+\frac{b_{i}^{\prime}}{a_{i}}\right) & =f\left(1+\frac{b_{1}^{\prime}}{a_{k}^{*}}\right)+f\left(1+\frac{b_{l}^{\prime}}{a_{1}^{*}}\right)+\sum_{\substack{i=2 \\
i \neq l}}^{n} f\left(1+\frac{b_{i}^{\prime}}{a_{i}}\right) \\
& \leqq f\left(1+\frac{b_{1}^{\prime}}{a_{1}^{*}}\right)+\left\{f\left(1+\frac{b_{l}^{\prime}}{a_{k}^{*}}\right)+\sum_{\substack{i=2 \\
i \neq l}}^{n} f\left(1+\frac{b_{i}^{\prime}}{a_{i}}\right)\right\} \\
& \leqq f\left(1+\frac{b_{1}^{\prime}}{a_{1}^{*}}\right)+\sum_{i=2}^{n} f\left(1+\frac{b_{i}^{\prime}}{a_{1}^{*}}\right)=\sum_{i=1}^{n} f\left(1+\frac{b_{i}^{\prime}}{a_{i}^{*}}\right),
\end{aligned}
$$

and the right inequality of (3) is proved.

If equality holds in the right inequality of (3), then equality holds in all the inequalities of (10). Hence, using the proved equality statement for $n=2$ and the induction hypothesis for $n-1$, it follows that

$$
a_{1}^{*}=a_{k}^{*}=a_{1}=a_{\imath}
$$

or

$$
b_{1}^{\prime}=b_{l}^{\prime}
$$

holds, and

$$
\begin{aligned}
& \left(\frac{b_{2}^{\prime}}{a_{2}^{*}}, \cdots, \frac{b_{n}^{\prime}}{a_{n}^{*}}\right) \text { is a rearrangement of } \\
& \qquad\left(\frac{b_{2}^{\prime}}{a_{2}}, \cdots, \frac{b_{l-1}^{\prime}}{a_{l-1}}, \frac{b_{l}^{\prime}}{a_{1}}, \frac{b_{l+1}^{\prime}}{a_{l+1}}, \cdots, \frac{b_{n}^{\prime}}{a_{n}}\right) .
\end{aligned}
$$

Combining (11) or (12) with (13), it follows that $b^{\prime} / a^{*}$ is a rearrangement of $b^{\prime} / a$, and the proof of the right inequality is completed.

The proof of the left inequality is similar.

For $f(x)=\log x$, (3) reduces to (1)'. We note that although $F(x)=x$ is not strictly convex, the statement of equality appearing in (3) holds true for this case too. This follows from the fact that the general equality statement for $n \geqq 3$ was derived only from its validity for $n=2$, and for $f(x)=\log x$ it is easy to check directly that it holds for $n=2$.

Theorem 2. Let $a=\left(a_{1}, \cdots, a_{n}\right)$ and $b=\left(b_{1}, \cdots, b_{n}\right)$ be n-tuples satisfying $a_{i}>0$ and $b_{i} \geqq 0, i=1, \cdots, n$. Let $f(x)$ be a real valued function defined and convex for $x \geqq 0$ and satisfying $f(0) \leqq f(x)$ for $x \geqq 0$. Then

$$
\sum_{i=1}^{n} f\left(\frac{b_{i}^{\prime}}{a_{i}^{\prime}}\right) \leqq \sum_{i=1}^{n} f\left(\frac{b_{i}^{\prime}}{a_{i}}\right) \leqq \sum_{i=1}^{n} f\left(\frac{b_{i}^{\prime}}{a_{i}^{*}}\right) .
$$

If $f(x)$ is strictly convex, then the same equality statement as in Theorem 1 holds. 
Proof. For $n=2$, (14) becomes: Let $0<a_{1} \leqq a_{2}$ and $0 \leqq b_{1} \leqq b_{2}$. Then

$$
f\left(\frac{b_{1}}{a_{1}}\right)+f\left(\frac{b_{2}}{a_{2}}\right) \leqq f\left(\frac{b_{1}}{a_{2}}\right)+f\left(\frac{b_{2}}{a_{1}}\right) \text {. }
$$

As before, we first prove the theorem for $n=2$. Denote

$$
\frac{b_{1}}{a_{1}}=x_{1}, \quad \frac{b_{2}}{a_{2}}=x_{2}, \quad \frac{b_{2}}{a_{1}}=y_{1}, \quad \frac{b_{1}}{a_{2}}=y_{2} .
$$

Using (2) for $n=2$, we obtain

$$
\left\{\begin{array}{l}
x_{1} \leqq y_{1}, \quad x_{2} \leqq y_{1} \\
x_{1}+x_{2} \leqq y_{1}+y_{2}
\end{array}\right.
$$

From (16) it follows that $x=\left(x_{1}, x_{2}\right)$ lies in the convex hull of the set of vectors $\left(\delta_{1} y_{\tau(1)}, \delta_{2} y_{\tau(2)}\right)$.

From here on the proof proceeds very similar to the proof of Theorem 1, and we omit the details.

For $f(x)=x$, (14) reduces to (2)'. The equality statement of Theorem 1 holds, as before, also in this case, although $f(x)$ is not strictly convex.

We bring an additional example. The function $f(x)=x \log (x+1)$ is strictly convex for $x \geqq 0$ and satisfies $f(0) \leqq f(x)$. Hence, applying Theorem 2, we obtain

$$
\begin{aligned}
\sum_{i=1}^{n}\left(\frac{b_{i}^{\prime}}{a_{i}^{\prime}}\right) \log \left(1+\frac{b_{i}^{\prime}}{a_{i}}\right) & \leqq \sum_{i=1}^{n}\left(\frac{b_{i}^{\prime}}{a_{i}}\right) \log \left(\frac{b_{i}^{\prime}}{a_{i}}+1\right) \\
& \leqq \sum_{i=1}^{n}\left(\frac{b_{i}^{\prime}}{a_{i}^{*}}\right) \log \left(\frac{b_{i}^{\prime}}{a_{i}^{*}}+1\right)
\end{aligned}
$$

or

$$
\prod_{i=1}^{n}\left(\frac{b_{i}^{\prime}}{a_{i}^{\prime}}+1\right)^{b_{i}^{\prime} / a_{i}^{\prime}} \leqq \prod_{i=1}^{n}\left(\frac{b_{i}^{\prime}}{a_{i}}+1\right)^{b_{i}^{\prime} / a_{i}} \leqq \prod_{i=1}^{n}\left(\frac{b_{i}^{\prime}}{a_{i}^{*}}+1\right)^{b_{i}^{\prime} / a_{i}^{*}}
$$

\section{REFERENCES}

1. G. H. Hardy, J. E. Littlewood, and G. Pólya, Inequalities, Cambridge, 1934.

2. H. Minc, Rearrangement inequalities (to appear).

3. L. Mirsky, On a convex set of matrices, Arch. der Math. 10 (1959), 88-92.

4. A. Oppenheim, Inequalities connected with definite hermitian forms, II, Amer. Math. Monthly, 61 (1954), 463-466.

5. H. D. Ruderman, Two new inequalities, Amer. Math. Monthly, 59 (1952), 29-32.

Received February 26, 1970.

Technion, IsRael Institute of Technology

HAIFA, ISRAEL 



\section{PACIFIC JOURNAL OF MATHEMATICS}

\section{EDITORS}

H. SAMELSON

Stanford University

Stanford, California 94305

\section{Richard Pierce}

University of Washington

Seattle, Washington 98105
J. DugundJI

Department of Mathematics

University of Southern California

Los Angeles, California 90007

RICHARD ARENS

University of California

Los Angeles, California 90024

\section{ASSOCIATE EDITORS}

\section{E. F. BeCKenBACH}

B. H. NeUmanN
K. YosHida

\section{SUPPORTING INSTITUTIONS}

\author{
UNIVERSITY OF BRITISH COLUMBIA \\ CALIFORNIA INSTITUTE OF TECHNOLOGY \\ UNIVERSITY OF CALIFORNIA \\ MONTANA STATE UNIVERSITY \\ UNIVERSITY OF NEVADA \\ NEW MEXICO STATE UNIVERSITY \\ OREGON STATE UNIVERSITY \\ UNIVERSITY OF OREGON \\ OSAKA UNIVERSITY \\ UNIVERSITY OF SOUTHERN CALIFORNIA
}

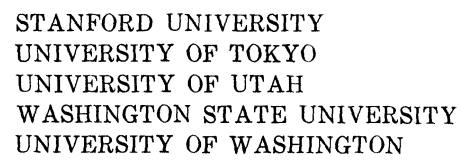

STANFORD UNIVERSITY UNIVERSITY OF TOKYO

UNIVERSITY OF UTAH

WASHINGTON STATE UNIVERSITY

UNIVERSITY OF WASHINGTON

The Supporting Institutions listed above contribute to the cost of publication of this Journal, but they are not owners or publishers and have no responsibility for its content or policies.

Mathematical papers intended for publication in the Pacific Journal of Mathematics should be in typed form or offset-reproduced, (not dittoed), double spaced with large margins. Underline Greek letters in red, German in green, and script in blue. The first paragraph or two must be capable of being used separately as a synopsis of the entire paper. The editorial "we" must not be used in the synopsis, and items of the bibliography should not be cited there unless absolutely necessary, in which case they must be identified by author and Journal, rather than by item number. Manuscripts, in duplicate if possible, may be sent to any one of the four editors. Please classify according to the scheme of Math. Rev. Index to Vol. 39. All other communications to the editors should be addressed to the managing editor, Richard Arens, University of California, Los Angeles, California, 90024.

50 reprints are provided free for each article; additional copies may be obtained at cost in multiples of 50 .

The Pacific Journal of Mathematics is published monthly. Effective with Volume 16 the price per volume (3 numbers) is $\$ 8.00$; single issues, $\$ 3.00$. Special price for current issues to individual faculty members of supporting institutions and to individual members of the American Mathematical Society: $\$ 4.00$ per volume; single issues $\$ 1.50$. Back numbers are available.

Subscriptions, orders for back numbers, and changes of address should be sent to Pacific Journal of Mathematics, 103 Highland Boulevard, Berkeley, California, 94708.

PUBLISHED BY PACIFIC JOURNAL OF MATHEMATICS, A NON-PROFIT CORPORATION

Printed at Kokusai Bunken Insatsusha (International Academic Printing Co., Ltd.), 7-17, Fujimi 2-chome, Chiyoda-ku, Tokyo, Japan. 


\section{Pacific Journal of Mathematics}

\section{Vol. 34, No. 3 \\ July, 1970}

Richard Hindman Bouldin, The peturbation of the singular spectrum

Hugh D. Brunk and Søren Glud Johansen, A generalized Radon-Nikodym derivative .

Henry Werner Davis, F. J. Murray and J. K. Weber, Families of $L_{p}$-spaces

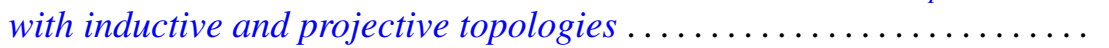

Esmond Ernest Devun, Special semigroups on the two-cell .

Murray Eisenberg and James Howard Hedlund, Expansive automorphisms

of Banach spaces ......................................

Frances F. Gulick, Actions of functions in Banach algebras.

Douglas Harris, Regular-closed spaces and proximities.

Norman Lloyd Johnson, Derivable semi-translation planes . .

Donald E. Knuth, Permutations, matrices, and generalized Young

tableaux..........................................

Herbert Frederick Kreimer, Jr., On the Galois theory of separable

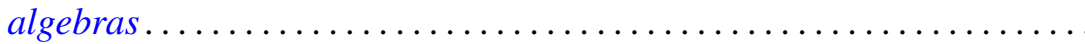

You-Feng Lin and David Alon Rose, Ascoli's theorem for spaces of

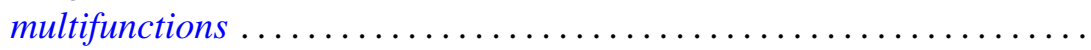

David London, Rearrangement inequalities involving convex functions . . . .

Louis Pigno, A multiplier theorem.

749

Helga Schirmer, Coincidences and fixed points of multifunctions into trees.

755

Richard A. Scoville, Some measure algebras on the integers .

Ralph Edwin Showalter, Local regularity of solutions of Sobolev-Galpern

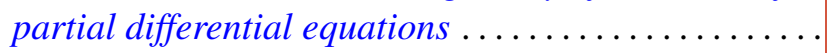

Allan John Sieradski, Twisted self-homotopy equivalences

John H. Smith, On S-units almost generated by S-units of subfields ...

803

Masamichi Takesaki, Algebraic equivalence of locally normal

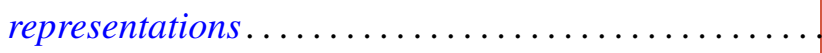

Joseph Earl Valentine, An analogue of Ptolemy's theorem and its converse in

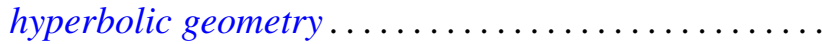

David Lawrence Winter, Solvability of certain p-solvable linear groups of finite order 